\title{
The use of fluids and cardiovascular acting drugs in nordic intensive care units 2014 - an internet- based cross-sectional practice survey
}

\author{
F Wickbom ${ }^{1 *}{ }^{*}$, M Kollind ${ }^{2 *+}$, E Wilkman ${ }^{3}$, M Snäckestrand ${ }^{4}$, A Oldner $^{5}$, A Perner $^{6}$, A Åneman ${ }^{7}$, M Chew ${ }^{1}$, \\ Scandinavian Critical Care Trials Group
}

From ESICM LIVES 2015

Berlin, Germany. 3-7 October 2015

\section{Introduction}

Shock is common in the intensive care units (ICUs) and is treated with fluids and vasoactive drugs. In 2003 a Scandinavian practice survey was performed documenting an extensive use of colloids and dopamine (1). In the last decade new research has questioned these practices $(2,3)$. Hemodynamic monitoring and evaluation is also under debate.

\section{Objectives}

To identify current practice for the treatment of shock in Nordic ICUs. Primary outcomes were the type of vasopressor and/or inotropic (VP/I) drugs and resuscitation fluids used. Secondary outcomes was the type of hemodynamic monitoring used and desired target values.

\section{Methods}

An observational descriptive cross-sectional study in intensive care units in Denmark, Finland, Norway and Sweden. Patients were included if in shock and older than 14 years with at least 4 hours of continuous VP/I -drug infusion during a 7-day inclusion period in July and August 2014. Pre-specified subgroup analysis for patients with sepsis and cardiac failure were performed.

\section{Results}

171 patients were included. Median Sequential Organ Failure Assessment (SOFA) score was 8 and $80 \%$ were mechanically ventilated. $82 \%$ had received VP/I-drug

+ Contributed equally

${ }^{1}$ Hallands Sjukhus, Dept of Anaesthesia and Intensive Care, Halmstad, Sweden

${ }^{2}$ Hallands Sjukhus, Dept of Surgery and Oncology, Halmstad, Sweden Full list of author information is available at the end of the article therapy $<24 \mathrm{~h}$ at inclusion. $84 \%$ received volume loading before onset of VP/I-drug treatment. Ringer's solution was given in $90 \%$ of patients and starches in 3/143 patients. Hypotension was the most common indication for VP/I-drug therapy (95\%). Noradrenaline was the most commonly used VP/I-drug, given in $98 \%$ of cases. $21 \%$ received treatment with more than one VP/I drug. Dopamine was used in $2 / 170$ patients. $97 \%$ were monitored with invasive arterial blood pressure. MAP, followed by lactate and diuresis were considered the most important variables for monitoring. The pulmonary arterial catheter was used in $16 \%$, arterial pulse wave analysis in $7 \%$ and echocardiography in $29 \%$.

\section{Conclusions}

Significant changes in fluid and vasopressor use have occurred within the last 10 years in Nordic ICUs. Ringer's solution and Noradrenaline are now used as first line treatment in early shock and the use of starches and dopamine is rare. Although most patients were monitored with invasive arterial blood pressure, more comprehensive hemodynamic monitoring was surprisingly used only in a minority of patients.

\section{Grant Acknowledgment}

Supported by The Research Council of Halland County Council, Sweden.

\footnotetext{
Authors' details

'Hallands Sjukhus, Dept of Anaesthesia and Intensive Care, Halmstad, Sweden. ${ }^{2}$ Hallands Sjukhus, Dept of Surgery and Oncology, Halmstad, Sweden. ${ }^{3}$ Helsinki University Central Hospital, Dept of Anesthesiology, Intensive Care, Emergency Medicine and Pain Medicine, Helsinki, Finland. ${ }^{4}$ Sahlgrenska University Hospital, Dept. of Anaesthesia and Intensive Care, Gothenburg, Sweden. ${ }^{5}$ Karolinska University Hospital, Dept of
}

(c) 2015 Wickbom et al.; This is an Open Access article distributed under the terms of the Creative Commons Attribution License (http:// creativecommons.org/licenses/by/4.0), which permits unrestricted use, distribution, and reproduction in any medium, provided the original work is properly cited. 
Anaesthesiology, Surgical Services and Intensive Care, Stockholm, Sweden. ${ }^{6}$ Copenhagen University Hospital - Rigshospitalet, Dept of Intensive Care, Copenhagen, Denmark. 'Liverpool Hospital, Dept of Intensive Care, Sydney, Australia.

Published: 1 October 2015

\section{References}

1. Oldner A, Rossi P, Karason S, Aneman A, Scandinavian Critical Care Trials Group: A practice survey on vasopressor and inotropic drug therapy in Scandinavian intensive care units. Acta Anaesthesiol Scand 2003, 47(6):693-701, Jul.

2. De Backer D, Biston P, Devriendt J, Madl C, Chochrad D, Aldecoa C, et al: Comparison of dopamine and norepinephrine in the treatment of shock. N Engl J Med 2010, 362(9):779-789, Mar 4.

3. Perner A, Haase N, Guttormsen AB, Tenhunen J, Klemenzson G, Aneman A, et al: Hydroxyethyl starch 130/0.42 versus Ringer's acetate in severe sepsis. N Engl J Med 2012, 367(2):124-134, Jul 12.

doi:10.1186/2197-425X-3-S1-A155

Cite this article as: Wickbom et al: The use of fluids and cardiovascular acting drugs in nordic intensive care units 2014 - an internet-based cross-sectional practice survey. Intensive Care Medicine Experimental 2015 3(Suppl 1):A155.

\section{Submit your manuscript to a SpringerOpen ${ }^{\mathcal{O}}$ journal and benefit from:}

- Convenient online submission

- Rigorous peer review

- Immediate publication on acceptance

- Open access: articles freely available online

- High visibility within the field

- Retaining the copyright to your article

Submit your next manuscript at $\gg$ springeropen.com 